\title{
Literary Performance in the Act of Pendendang
}

\author{
Noni Sukmawati \\ Graduate School, Indonesia Institute of Art Yogyakarta, Indonesia \\ email: nonisukma@yahoo.com
}

\begin{abstract}
This study is aimed to find out the power of pendendang as the main actor in Sastra Pertunjukan (Literary Performance), an art performance which places literature - in this case pantun or verse as the spoken literature of Minangkabau - as the main medium. Pantun is delivered through berdendang or singing tradition which is accompanied by an instrument named saluang. Hence this performance is so called saluang dendang performance. The main strength of this performance is the selection of the pantun delivered by pendendang and his ability to build a contextual connection or to interact with the audience or the surroundings.Pendendang combines the pantun with the new pantun and creates new ones spontaneously and contextually in his live performance. Therefore, this art performance of Minangkabau is also a literary performance because of the main strength lies on the pantun that are delivered. Framed in the theoretical proposition of Pierre Felix Bourdieu, this study tries to recite the role and the pendendang's strength to improvise in his efforts to create an interesting performance for the audience, through his selection of pantunthat is delivered spontaneously and his mastery, habitus and position in the performance.

Keywords: habitus, mastery, practice, performance, pendendang.
\end{abstract}

\section{INTRODUCTION}

Minangkabau is an ethnic society that supports a distinctive cultural tradition that is called Minangkabau culture. Therefore, the word Minangkabau means a cultural tradition, a view of life, and also a name of an ethnic group in western part of Sumatera. Some researchers who have dichotomous views state that Minangkabau society is the largest matrilineal society in the world. This is not entirely true because Minangkabau people also follow patrilineal line based on Islam as the only religion as the guidance of Minangkabau society.

Minangkabau runs a system to maintain harta pusaka tinggi (high heritage) of the clan that is the heritage and legacy from the ancestors that is inherited to the next generation matrilineally. Heritage for them is material things like fields, lands, and livestock. While legacy is like charisma, title, and noble relics as the dignity of the clan. The clan dignity is an important aspect for Minangkabau people. Thus, all the male members of the clan are the also the protectors of the female members in the clan. 
Minangkabau society is also well-known with its strong merantau (wandering) tradition. Although there is no valid data of the specific number, Naim (1984: 30) states that the amount of Minangkabau people who leave the homeland is almost equivalent with the number of people in West Sumatera. The population of Minangkabau people in West Sumatera is approximately 10 million. According to Naim's analysis, half of them live in West Sumatera and the other half wander all over Indonesia.

The traditional habitation of Minangkabau people is called kampung halaman or ranah (homeland). It is a highland area in West Sumatera with narrow valleys and fertile soil. This habitation is named Luhak Nan Tigo (Three Areas) that consists of three regents and three cities. These areas are stretched out with slopes and valleys of Mount Merapi, Mount Singgalang, and Mount Sago.

The main livelihood of Minangkabau people in their homeland is farming and some of them are merchants. Dobbin (1992: 1-9) describes beautifully geographic characteristics of the traditional habitation of Minangkabau which influences the cultural pattern that is based on agriculture.

Many traditional arts grow and develop in Minangkabau society. According to Navis (1981/1982: 95), Minangkabau art is mainly grouped into three; (1) darek (highland) art that is related to farming characteristics; (2) pesisir (coastal) art which has seaport characteristics; (3) Islamic art.

One of the darek art is saluang dendang performance. This performance exists in Minangkabau society and culture. It is a performance with a traditional flute named saluang. It is performed by minimal three artists; one saluang player and two pendendang or singers.

There is an intense interaction between the singers and the audience in a saluang dendang performance. That interaction is built through pantun or verses that are delivered. It contains messages as Murgianto (2016: 53) states: "Performance is a series of communication from one or more people as the messengers who are responsible to one or more receivers and to tradition that they understand as a set of specified behaviors." Therefore, a performance is a number of human acts that brings about communication to deliver and receive certain messages from their traditions. If we use this definition to explain saluang dendang performance, in this case the saluang player and the singers are the messengers and the audience is the receivers of the messages.

The messages that are delivered through the pantun and songs are in the local Minangkabau language whereas the culture that is delivered is Minangkabau culture. Generally we can say that people who are involved in the performance are Minangkabau people who understand Minangkabau language. The messages delivered in saluang dendang performance are unique musicality from the saluang, but the most important message is the pantun, which are included in oral tradition. Pantun is delivered by the singers spontaneously. It is notnecessarily 
related to the title or the rhythm of the songs. A pantun can be created especially for the songs in the saluang dendang performance. The spontaneity of the singers who are sensible to the situation and ambience of the performance is an interesting phenomenon for a study.

\section{THEORETICAL BACKGROUND}

The theoretical background used in this study of Literary Performance in the Act of Pendendang is the theory of the field of cultural production that is developed by Pierre Bourdieu. This theory basically is a theoretical frame based on the sociology of art which discusses on how to comprehend artworks as a whole manifestation field (Bourdieu, 2012: 16). According to Bourdieu (2012: 215), field is the real social universe, a setting in which--- as the specific rules of the field applied--- certain capitals are accumulated and a setting which ishierarchical. Based on that definition, society, according to Bourdieu (in Mahar, 2009: 45), is a field system that has a system and relations. Each field has a structure and power. Most are subordinate to the larger field of power and class relations.

Based on Pierre Bourdieu's context on the field of cultural production, there are at least three characteristics of field. First characteristic, a field can be seen as an arena in which people struggle to pursuit power or legitimacy. Pierre Bourdieu (2012: 193) states that as an arena, field can be seen as latent potential power that influences every related particle in it, it can also be consider as a battle arena. The second characteristic, a field has structured spaces in which there are some types of capitals. The space that forms a field is a result of interactions from competing individuals. However in the practice they are united by their dialectical relation. Capital, according to Bourdieu (2012: 194) in theory of field of cultural production context, is an inherited asset that creates inherent possibilities in the field.

The third characteristic, a field provides spaces for each agent to act in a specific rules and battle. According to Pierre Bourdieu (2012: 28-29) the agents involved in a cultural field might not have similarities but they participate in the battle to impose the definition of legitimacy on the cultural production. The fourth characteristic, a field is structured based on internal mechanism which is autonomous relatively. As a structured, autonomous, and relative space, the field is temporary. This causes each transformation of the field structure referring to the changes of structured taste that is a distinctive system between groups.

In a field of game, there is always a variable at stake. Bourdieu (2012: 193-194) states it as habitusandcapital. Habitus - the properties obtained, conceived and assimilated, such as flexibility, self-contained calmness, beauty and so on --- and capital is inheritance assets that determine the inherent possibilities in the field. Habitus is an important concept in PierreBourdieu's theory of field of cultural production. Habitus according to Bourdieu (in Harker, 2009: 13), is a durable, transposable disposition that functions as a generative basis of practices that are structured and guided objectively. 
According to Bourdieu, disposition covers three meanings; (1) the result of a regulating action, a series of results which he describes as something that projects the structure; (2) how to be or habitual conditions, (3) tendencies, intentions or tendencies. Dispositions that alter habitus are generative and praxis base, have a causal link between habitus and non-mechanical or deterministic praxis; habitus guides the agent to do one thing and provides a basis for the formation of praxis (Jenkins, 2013: 110-2).

While Ritzer (1996: 72) argues that habitus is a dialectical process of internalization-externalization and externalization-internalization. Habitus refers to a number of dispositions that are created and formulated through a combination of objective structure and personal history. Dispositions are obtained in various social positions within a single field, and imply a subjective adjustment to that position. Habitus also includes one's knowledge and understanding of the world, contributing to the reality of the world, and creating a genuinely real world form of reality and not merely a reflection of the real world. Habitus is also closely linked to capital, since habitus also serves as a multiplier of different types of capitals. And, in fact, habitus creates a form of capital (symbolic) in and of itself (Harker, 2009: 15).

According to Bourdieu, capital is a concentrated power, it is a specific power practiced in the field. It is the field of power which is at the same time is the field for people to change the structure. While the relationship between the arena, habitus, and capital is direct. The value of capital is attributed to various social and cultural characteristics of the habitus. For Bourdieu (1977: 178), capital acts as a social relation contained in a system of exchange, and the term is extended to all forms of goods, both material and symbolic.

In addition to the arena, habitus and capital, in the theory of the field of cultural production, there are also so-called practices. Practice or action is the result of relationships between habitus, capital and field. Practice as a field, habitus, and capital product as a force, has two types of action, ie strategy and trajectory. Strategy is the way agents work in the arena of constructing their social world and acting to produce their positions to gain a position within the social world. The trajectory in Bourdieu's sense (2010: 58) is a series of successful movements of an agent in a structured space (hierarchy), which may undergo change and distortion, or more precisely, within the distribution structure of the different types of capital at stake in the field, economic capital and specific consumptive capital. But Mahar (2009: 25) reminds, in social space not only the individual positions that can be determined, but more importantly, how they arrive at certain positions through the use of the concept of trajectory.

\section{FIELD, HABITUS, AND PENDENDANG'S RECONVERSY CAPITAL}

The stage for saluang dendang performance, as an inherent part in culture and society life, processes through habitual condition in Minangkabau cultural field. The saluang performance field is born from the history of struggle or power 
struggles and cultural legitimacy between agents within the cultural field. Saluang dendang show is one of many other fields, which are within the field of cultural power called Minangkabau.

Minangkabau is a social space consisting of various arenas of power that attract each other and struggle for legitimacy. There is a power field of customary leaders called penguhulu and other informal leaders. There is an arena of power from the clerics and religious leaders of Islam. There is a country arena with the power of hegemony. There is a social system of matrilineal kinship, which has certain restrictions for women. There is a field of pop culture (mass culture) that becomes a competitor of the performance of saluang dendang performing arts, offering a new orientation for the Minangkabau community.

In the midst of the various fields in Minangkabau this, the growth and development of saluang dendang literary performance, with the main actor is female pendendang. Female pendendang in the life of saluang art performances, that are public, is actually a relatively new phenomenon. According Sukmawati (2006: 1 ), there is a tendency in Minangkabau women taboo to appear as a pendendang, furthermore in the form of performances that are intended for the public. This phenomenon only emerged and developed after the second half of the 20th century, precisely after the regional upheaval called the revolutionary named Pemerintahan Revolusioner Republik Indonesia (PRRI) at the end of 1950s, based in the Minangkabau realm.

The field of performances saluang dendang is of course not apart from social reality in the field that surrounds it. The changes and developments that took place in the field of saluang dendang performance are certainly the implications of what happened in the big arena called Minangkabau. Sukmawati (2006: 209) mentions, what happens in the field of saluang dendang performance and the emergence of female pendendang as a new actor is a result of social changes that occur in Minangkabau cultural field. In other words, female pendendang manage to seize the space in saluang dendang performance, which in the past occupied by men. They manage to become new agents (actors) in saluang dendang performance.

Female pendendang is a newcomer in the field of performing arts. Yet their existence is well welcomed by the audience. It proves that there is a potential capital gained by female pendendang. To be able to understand the source of that potential capital we need to study the habitual conditions that create it.

Sukmawati (2006: 117) states in general when it is viewed from the level of education, from five female pendendang studied, only one person who graduated from high school, while the rest did not even finishtheir elementary education.

So it can be said that the pendendang in saluang dendang literary performance, their habitus is formed or inherited from their social environment.

We can say that the formal education system has little effect on the formation of their habitus. However they are quite successful in using their experience, knowledge, abilities as a female pendendang in the field of saluang dendang performance. In addition, most of them come from humble family background. 
Nevertheless, the cultural traditions they live in have become a potential habitus as an important cultural capital for female pendendang.

The capital used or at stake by pendendang in the saluang dendang field, their main capital, is the cultural heritage of the Minangkabau society which is their way of life. It is the Minangkabau cultural heritage in the form of an agrarian culture based on oral tradition. The cultural heritage which is based on oral tradition, in which words are formed and structured in poetic form, is a living literature that can be read every time by pendendang. So the daily experience of pendendang living in an oral cultural society provides a rich knowledge and experience to pendendang. This background becomes their main capital to gain their legitimacy as pendendang in the field of saluang dendang, whose main strength lies in the pantun they sing, thus they can deliver a form of enthralling literary performance.

Therefore there are two potential cultural capitals that can be converted into self potential for female pendendang. On one hand, the life of Minangkabau people is full of implicit language expressed in pantun and adagium culture. On the other hand, as Muslims, Minangkabau children are accustomed to knowing tajwid in the recitation of the Qur'an which is their guidance in life. For the majority of Minangkabau people, their unique identity is characterized by the two potential awesomeness, namely the linguistic potential by understanding the implicit language spontaneously as a response to their speaking partners and by being able to recite the verses in Qur'an well. Both traditions sharpen their vocal abilities and language sensitivity, including memorizing hundreds of songs/rhythms.

There have been no studies that specifically collect how many songs to the existing saluang dendang performance today. But certainly pendendang must have the ability to master almost all the repertoire of saluang performances songs in addition to the ability to create new rhymes. The ability to master a song without musical score and without written rhyme texts requires a high musical taste and sensibility.

Performers in saluang dendang must be able to sing songs in accordance with the request of a diverse audience. Therefore, a saluang player is a musical artist who must master all the repertoire of songs saluang widely known by the public. The player is the first to start with the music of the song, and then pendendang play their roles. While pendendang must master a large number of pantun, and try to combine it or deliver it with poems related to the context of the performance. For example, he can create a spontaneous pantun about the audience, or capture the inner mood of those present to be expressed, resulting in a dynamic interaction during the performance

Nevertheless, the world of entertainment is the world of men. Women who enter this world of men still can not freely express themselves. Therefore, the body language of the female pendendang is a lot different with those singers who rely on their voice in the performance generally. Female pendendang always bows down, and uses the deep voice from their throats, not the voice from diaphragm as in the common vocal technique. 
Sukmawati (2006: 151-153) sees quite a lot of people cannot accept the existence of women as pendendang, and underestimate their social status, because singing in the field of saluang dendang performance, is not a decent job for Minangkabau women. Some also cannot accept it because Islam forbids women to act like that. Yet there are still number of people who support, even worship them as pendendang. They make saluang dendang performances survive in various places in Minangkabau, although there are certain groups of society who still do not like this performance. This means female pendendang can be considered to have succeeded in developing a new social reality, and seized the legitimacy in the field of saluang dendang, as mentioned in the theory of the field of cultural production by Pierre Bourdieu.

The competence of the saluang player and pendendang is developed through autodidact; no special trainers to teach them. They start by asking, observing, and practicing it themselves. Then they do the internship by attending some performances and becoming pendendang without any payment. In turns they sing the songs with the senior pendendang. From this internship process, he can be a professional pendendang then people start to invite and pay him as the system applied.

\section{THE PERFORMING ART FIELD}

The field of saluang dendang performance presents a dialogical meeting between the messenger and the receiver of the message. In this case, the messenger is saluang dendang performers, and the receiver is the audience or the listener. The performers are called the messengers because most of the time, the messages delivered are also messages from the audience. The field is basically an interactive performance space. It means that the structure of the saluang dendang performance is formed and carried out based on the active participation of the audience and the expertise of the performers to respond creatively.

The field of saluang dendang performance is formed based on the interests of certain group as the host who organizes the performance. The organizer will choose his preferable pendendang to perform in their event. The choice can be varied as long as there are minimum three performers; one saluang player and two singers. One saluang player (male) plays the instrument and accompanied with, usually, two female singers. According to Sukmawati (2006; 115-116) women dominate the field of saluang dendang performance and it is rare now to find male singers. The development of the saluang dendang performance is getting more interesting now with the shift in the existence of more female performers than male performers on stage though there is no change in the shape of the performance.

The stage of saluang dendang performance is not a battle of aesthetic visuals like dances and theatrical performances. Saluang dendang performance does not use body as the strength of the artistic expression. There is no physical performance on stage. The stage is also much different from the conventional stage like people 
use for dances and theatrical performance. Saluang dendang performance does not require artistic stage management and special lightings. It does not need a special place. This performance can be carried out anywhere as long as there is a space as a meeting point. The dynamics of saluang dendang performance is very static. The performers sit cross-legged on a mat on a corner of the room during their performance. They use a simple loudspeaker so that the audience can hear them from a distance. The performers do not show attractive movements; they usually sit and stare at the mat while singing.

With the minimum artistic and aesthetic and far from visual body exploration, how can the performers enliven the stage? In the battle arena, what power should the performers gain?

The performance starts at $9 \mathrm{pm}$ and finishes the next day at $4 \mathrm{am}$. During the show, the saluang dendang performers play songs as requested by the audience and each pendendang tries to compose the pantun related to the audience who request the songs. He mentions the name of the audience and chooses a pantun that is based on the condition or psychological situation that is happening there. If the content fits to the context, there is a spontaneous response from the audience that makes the performance interesting and lively. For example the following pantun:

\section{Lagu iko nan kanduang mintak \\ Bialah kami dendangkan juo \\ Lah putuih hati dek taragak \\ Badan batamu sariak juo ${ }^{1}$}

Sometimes the audience asks the performers to repeat the same pantun. Then the performers repeat and mention the name of the audience who requests the same pantun:

\section{Lagu iko nan bamintak Baulang pantun disuruahnyo \\ Lah putuih hati dek taragak \\ Mak Ajis di subarang juo ${ }^{2}$}

By doing it in a dialogical and interactive way, the pendendang tries to cope with the situation and condition of the audience so that they can choose suitable pantun. In this case, the structure of the saluang dendang performance is built and developed through literary performance that is oral performance; wellcomposed and improvised pantun during the performance. There are four kinds of pantun. The first one is pantun mudo ${ }^{3}$, a romantic pantun like the example above. The second one is pantun hiburan or jenaka (humorous). The third is pantun

$1 \quad$ This pantun simply means the pendendang states that// she sings the songs as requested// and she is singing it now / / she has been missing someone// but she can't meet the person.

2 This pantun means;//she will sing the song as requested//and repeat the same pantun// She has been missing someone// but Mak Ajis is so far away.// Mak Ajis is the name of the audience who asked the pendendang to repeat the pantun.

3 Pantun mudo is a romantic expression of the teenagers. 
nasihat (advice). The last one is pantun ratapan (mourning). Humorous pantun, for example:

Kok kandak alah kami bari

Alah ko hati ka sanang

Kabanyakan nan bujang kini

Salero tungggang ka nan usang ${ }^{4}$

Pantun nasehat (advice) contains advices about the local wisdoms in

Minangkabau culture:

Nak dialiah buah nyanyi

Agak batanang lai mandanga

Kalau pandai bamain budi

Di dalam aia indak kabasah ${ }^{5}$

Pantun ratapan (mourning) is as follows:

Kama dialiah mak pandangaran

Kama lah lagu dialiah sudah iko

Jo tangih denai mampaulehkan

Dek kanduang buhua baurak juo ${ }^{6}$

There are thousands of pantun exist; some are partially modified; the pendendang maintain the first and second line of the pantun and create new ideas in the third and fourth lines or simply repeat the previous lines. They can also create new pantun as advised by the society. This adds and develops the list of the pantun in saluang dendang performance. In other words, saluang dendang performance as a literary performance is simultaneously developed. Besides, the audience of saluang dendang performance is basically are people who have empiric knowledge about the oral tradition, including the list of songs. They have their own selection of their favorite songs. They frequently request the songs in the performance they attend. They also have the background knowledge of the songs and pantun they request. As they audience even know the charateristics of the saluang melody, a saluang player has to play it well.

This kind of audience comes not only to enjoythe performance but also to contribute some money to the performance organizer to pay the saluang dendang performers. In this case, we can say that a saluang dendang performance is a participative performance, in terms of the payment.

The connection between the performers and the audience, who are mostly villagers, is emotionally very close. There is a group of enthusiastic audience

$4 \quad$ This pantun means// Thesong has been sung//She hopes it is entertaining// Young men nowadays// prefer to choose older ones orusang. Implicitlyusang assumed as widows.

5 Literary it means;//Allow us to change the song// Please pay more attentions//if we can maintain our good values// We can't be wet in the water.

6 This means; // What song are we going to listen to// What song are we going to sing next?// I am trying to keep this (relationship) with tears// Why do you want to loose this tie, Sir? 
in each nagari or village where saluang dendang is usually performed. This group knows the performers well and this group can give reference to select recommended performers. This group also highly appreciates the local people where the performance exists. The saluang dendang performers sometimes ask this group for references about the local situation of the place they are going to perform. Therefore, saluang dendang performance has a widespread network in the villages in West Sumatera, more specifically, the networks between saluang dendang performers and their enthusiastic audience.

\section{SALUANG DENDANG AS A COLLECTIVE AWARENESS}

Pendendang are usually aware that what they deliver is a part of collective awareness of the audience. To understand the collective awareness, the pendendang have to mingle and get along with the society. They have to know the daily problems, and the social values in Minangkabau society. Generally the musical atmosphere in saluang dendang is ratapan or mourning that expresses sadness. Based on that, the pendendang should be able to express it in a mourning pantun that is called ratok.

This ability can be seen through their way to interact with the audience from all social class. The performers should be able to give equal attentions to the audience, so nobody feels ignored. In their interaction in the performance and outside the performance, the performers always want to show hospitality, politeness, dialogical and communicative attitudes. They want to show people that they are respectable women, although not all people can accept them wholeheartedly. The main capital used by pendendang in saluang dendang performance is the Minangkabau cultural heritage as their way of life. The Minangkabau cultural heritage is the agricultural tradition based on the oral tradition in which words are composed and structured poetically. It is like a living reference for pendendang that they can 'read' anytime. Thus, the daily experience of pendendang who live in a society with the oral tradition enriches their knowledge and experience. It becomes the main capital of pendendang to gain their legitimacy in the field of saluang dendang performance which the main strength lies on the lyrics in the pantun to create an attractive performance.

The next capital of pendendang is the experience on stage during the performance. Every field of saluang dendang performance for pendendang is the practice of an agent (actor) who not only gives cultural messages to the audience, but also receives messages from the audience. The structure of the performance is interactive and dialogical, causing the messengers are not only the actors on the stage, but also the audience in the field of the show.

The audience at the saluang dendang performance is an active audience. Generally, the audience at the saluang performance arena is male, although in some fields there are still women involved, but their number remains minority. The dominance of men as spectators at the saluang dendang performance has created a form of emotional-dialogical relationship, which encourages the male audience 
to play a more active role in the field. Their main roles are, among other things, reviving the structure of saluang dendang performance, ordering the songs and pantun, and then it is the duty of the pendendang to put it into practice. Not only that, quite a lot of the audience make their own pantun, either as a response to the pantun being sung, as well as a new discourse to enrich saluang performance as a literary performance.

The ability of saluang player and pendendang grows and develops autodidact, in the sense there is no special teacher who teaches them. They must begin by themselves by questioning, listening and trying it out for themselves. Then they do apprenticeship, being present at the saluang dendang performance and participate as pendendang without any payment. Songs that they master will be sung in turns with more senior pendendang. From this apprentice process they will eventually become professional pendendang, so that they are invited and paid according to the system.

\section{CONCLUSION}

Saluang dendang performance grows and develops well even though by shape it seems static because the performers only sit during the performance and there is no attractive physical performance like in dances or theatrical performance. Furthermore, there is no special attributes on stage like setting as the artistic media or special lighting to make the stage more attractive. The stage of saluang dendang performance simple and does not need a special space. Nevertheless this performance is an interesting cultural arena in Minangkabau society and culture.

The field grows and develops because of the cultural capital that makes it possible for pendendang to build his habitus, to gain legitimacy in a cultural arena of the performance. The cultural capital in a poetic oral traditionthat exists in Minangkabau society and the habitus of pendendang with their capability in delivering their practice as artists becomes the main strength of the development of saluang dendang field as the cultural field in Minangkabau. Therefore, the field of saluang dendang performance can also be called the field of literary performance.

The terminology of literary performance is not commonly used in the performance tradition in Minangkabau though there are some oral traditions that have grown and developed so far. Literary performance is more appropriate to define saluang dendang performance because what should be gained in the field of the performance, as Pierre Bourdieu's theory states, are the texts or pantun that are sung. Through the text of pantun literature, each agent (actor) shows their habitus and cultural capital.

\section{REFERENCES}

Bourdieu, Pierre. (1977). In Other Words: Essays towards a Theory of Practice. United Kingdom: Cambridge. University Press. . (1984). Distinction: a Social Critic of the Judgement of Taste. Cambridge-. Harvard University Press. 
. (2011). Pierre Bourdieu: Uraian \& Pemikiran (Choses Dites). Kreasi

Wacana. Yogyakarta.

(1996). The Rules of Art, Genesis and Structure of the Literary Field. Trans. Susan Emanuel. Cambridge. Polity Pres.

. (2012). Arena Produksi Kultural: Sebuah Kajian Sosiologi Budaya. Kreasi

Wacana. Yogyakarta.

Dobbin. Christine. (1992). Kebangkitan Islam dalam Ekonomi Petani yang Sedang Berubah, Sumatera Tengah 1784-1847. INIS.

Field, John. (2010). Modal Sosial. Kreasi Wacana. Yogyakarta.

Hadeler. Jeff. (2010). Sengketa Tiada Putus: Matriakat, Reformisme Islam, dan Kolonialisme di Minangkabau. Freedom Institute. Jakarta.

Harker, Richard, Cheelen Mahar, dan Chris Wilkes. (Ed) (2009). (Habitus x Modal) + Ranah $=$ Praktik. Jalasutra. Yogyakarta.

Jenkins, Richard. (2013). Membaca Pikiran Pierre Bourdieu. Kreasi Wacana. Yogyakarta.

Murgiyanto. Sal. (2016). Pertunjukan Budaya dan Akal Sehat. Komunitas Pertunjukan IKJ, Jakarta. Komunitas SENREPITA. Yogyakarta.

Naim. Muchtar. (1984), Merantau: Pola Migrasi Suku Minangkabau. Gajah Mada University Press. Yogyakarta.

Ritzer, George. (2014). Teori Sosiologi Modern. Edisi Ketujuh. Kencana. Jakarta.

Ritzer, George \& Barry Smart. (2014). Teori Sosial. Handbook. Nusa Media. Bandung.

Sukmawati, Noni. (2006). Ratapan Perempuan Minangkabau dalam Pertunjukan Bagurau: Gambaran Perubahan di Minangkabau. Andalas University Press. Padang. 